\title{
Analisis Produk Domestik Bruto, Infrastruktur, Nilai Tukar Dan Tingkat Suku Bunga Terhadap Investasi Asing Langsung Di Indonesia
}

\section{Analysis Of Broom Domestic Products, Infrastructure, Exchange Rate And Interest Rate Of Direct Foreign Investment In Indonesia}

\author{
Fuji Astuty * \& Ina Namora Putri Siregar** \\ Fakultas Ekonomi Universitas Prima Indonesia \\ Coresponding *Email: fujiastuty424@gmail.com, \\ **Email: inanamoraputri@gmail..com
}

\begin{abstract}
Abstrak
Penelitian ini bertujuan untuk memberikan bukti empiris tentang faktor-faktor yang mempengaruhi investasi asing langsung di Indonesia dalam perkembangan ekonomi global yang meliputi produk domestik bruto, infrastruktur, nilai tukar dan suku bunga untuk periode 1998 - 2015. Metode analisis yang digunakan adalah persamaan regresi linier berganda. dengan teknik analisis Ordinary Least Square (OLS) dan Error Correction Mechanism (ECM). Hasil empiris dari penelitian menunjukkan bahwa dalam jangka panjang variabel produk domestik bruto berpengaruh dan signifikan sedangkan variabel nilai tukar tidak berpengaruh signifikan. Dan variabel infrastruktur memiliki efek negatif tetapi tidak signifikan. Dalam variabel jangka pendek yang memiliki pengaruh positif dan signifikan adalah variabel-variabel produk domestik bruto, infrastruktur, dan nilai tukar. Sementara tingkat bunga tidak berpengaruh. Koefisien variabel yang menjelaskan variabel investasi langsung asing dalam pembangunan ekonomi global adalah infrastruktur terbesar, diikuti oleh produk domestik bruto dan nilai tukar rupiah. Koefisien determinasi $78,17 \%$ menunjukkan bahwa variasi dalam variabel produk domestik bruto, infrastruktur, nilai tukar dan suku bunga dapat menjelaskan variasi dalam variabel investasi asing langsung di Indonesia dalam pembangunan ekonomi global sementara sisanya $21,83 \%$ dijelaskan. oleh variabel lain yang tidak diteliti dalam penelitian ini.
\end{abstract}

Kata Kunci : Produk Domestik Bruto, Infrastruktur, Nilai Tukar dan Suku Bunga

\begin{abstract}
This study aims to provide empirical evidence about the factors that affect foreign direct investment in Indonesia in global economic developments which include gross domestic product, infrastructure, exchange rates and interest rates for the period 1998 - 2015. The analysis method used is multiple linear regression equation with analysis techniques Ordinary Least Square (OLS) and Error Correction Mechanism (ECM). The empirical results of the research show that in the long run the variable of gross domestic product is influential and significant while the variable of exchange rate has no significant effect. And infrastructure variables have a negative but insignificant effect. In the short term variables that have a positive and significant influence are the variables of gross domestic product, infrastructure, and exchange rates. While the interest rate has no effect. The coefficients of the variables that explain the variables of foreign direct investment in global economic development are the largest infrastructure, followed by gross domestic product and the rupiah exchange rate. The coefficient of determination of
\end{abstract}


Fuji A \& Ina Namora P.S. Analisis Produk Domestik Bruto, Infrastruktur, Nilai Tukar Dan Tingkat Suku Bunga Terhadap Investasi Asing Langsung Di Indonesia

$78.17 \%$ shows that variations in the variables of gross domestic product, infrastructure, exchange rates and interest rates are able to explain variations in the variables of direct foreign investment in Indonesia in global economic development while the remaining $21.83 \%$ is explained by other variables not examined in this research.

\section{Keyword: Gross Domestic Product, Infrastructure, Exchange Rate, Interest Rate}

How to Cite: Astuty, F. \& Siregar, I.N.P (2018). Analisis Produk Domestik Bruto, Infrastruktur, Nilai Tukar Dan Tingkat Suku Bunga Terhadap Investasi Asing Langsung Di Indonesia, Jurnal Konsep Bisnis dan Manajemen. 5 (1): 91-105 


\section{PENDAHULUAN}

Menjelang akhir triwulan III-2008, perekonomian dunia dihadapkan pada satu babak baru yaitu runtuhnya stabilitas ekonomi global seiring dengan meluasnya krisis finansial ke berbagai negara. Krisis finansial global mulai muncul sejak bulan Agustus 2007, yaitu pada saat salah satu bank terbesar Perancis BNP Paribas mengumumkan pembekuan beberapa sekuritas yang terkait dengan kredit perumahan berisiko tinggi AS (Subprime Mortgage). Pembekuan ini lantas mulai memicu gejolak di pasar finansial dan akhirnya merambat ke seluruh dunia. Di penghujung triwulan III-2008, intensitas krisis semakin membesar seiring dengan bangkrutnya bank investasi terbesar AS Lehman Brothers, yang diikuti oleh kesulitas keunagan yang semakin parah di sejumlah lembaga keuangan berskala besar di AS, Eropa, dan Jepang. Krisis keuangan dunia tersebut telah berimbas ke perekonomian Indonesia sebagaimana tercermin dari gejolak di pasar modal dan pasar uang. (Publikasi Bank Indonesia : 2009).

Kuatnya daya tahan dan membaiknya prospek ekonomi Indonesia meningkatkan kepercayaan investor asing mendorong semakin meningkatnya peran investasi asing langsung dalam struktur aliran modal masuk. Surplus investasi asing langsung atau FDI meningkat pada tahun 2011, sehingga peran investasi asing langsung dalam aliran modal masuk jauh meningkat dibandingkan dengan tahun sebelumnya. Tahun 2013, perekonomian global yang melemah di tengah struktur perekonomian domestik yang tidak mendukung mendorong penurunan investasi asing langsung di Indonesia. Transaksi investor domestik yang melakukan akuisisi saham asing pada perusahaan ritel serta perusahaan minyak dan gas di Indonesia juga berkontribusi pada penurunan investasi asing langsung di Indonesia. Perekonomian dunia yang melambat, ketidakpastian di pasar keuangan global yang meningkat, serta perlambatan perekonomian domestik pada 2015 menyebabkan investasi asing langsung mengalami penurunan kembali. Hal ini dapat diperlihat pada tabel 1.1 berikut ini : 
Fuji A \& Ina Namora P.S. Analisis Produk Domestik Bruto, Infrastruktur, Nilai Tukar Dan Tingkat Suku Bunga Terhadap Investasi Asing Langsung Di Indonesia

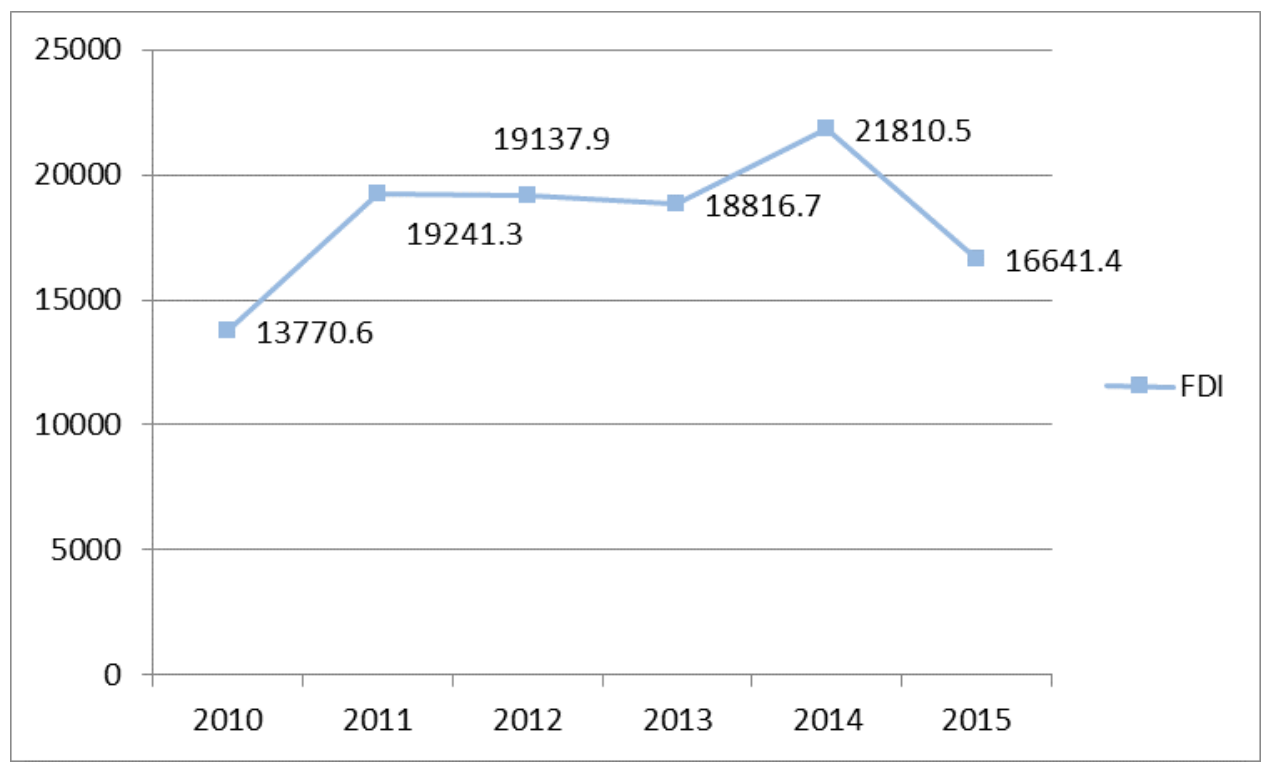

Gambar 1.1 Fluktuasi Investasi Asing Langsung di Indonesia Periode 2010 - 2015

Sumber : Bank Indonesia dan UNESCAP, (data diolah)

Tengah Bank Indonesia

Berdasarkan fenomena yang langsung (FDI) didefinisikan sebagai terjadi dan berbagai hal yang diuraikan di investasi jangka panjang yang dilakukan atas, maka peneliti membatasi secara langsung oleh investor asing di permasalahan pada : apakah terdapat dalam suatu bidang usaha warga negara pengaruh secara parsial dan simultan infrastruktur, nilai tukar, tingkat suku bunga dan produk domestik bruto riil (PDB riil) terhadap investasi asing langsung di Indonesia.

Investasi asing merupakan suatu kegiatan dalam menanamkan modal yang dilakukan oleh suatu negara ke negara lain. Modal asing dapat memasuki suatu negara dalam bentuk modal swasta dan/atau modal negara. Modal asing swasta dapat mengambil bentuk investasi langsung dan investasi tidak langsung. Investasi asing domestik (Kurniati dkk, 2007). Selain itu menurut pendekatan IMF, FDI adalah suatu investasi yang diadakan untuk memperoleh hak jangka panjang atas suatu usaha yang berada di luar ekonomi atau negara si penanam modal (Sitinjak, 2011). Investasi ini bertujuan untuk mendapatkan keuntungan di masa depan dengan harapan perusahaan yang diinvestasikan akan beroleh keuntungan dan mendapat hasil keuntungan dari pembagian hasil, tetapi apabila perusahaan mengalami kerugian maka 
investor juga akan mendapatkan bagi hasil yang merugi juga (Purba dkk, 2015).

Menurut Kurniati dkk (2007), secara garis besar terdapat 3 bagian besar faktor yang mempengaruhi perkembangan investasi asing langsung (FDI) di suatu negara, yaitu:

1. Kondisi ekonomi meliputi pertumbuhan ekonomi (GDP), biaya tenaga kerja, produktivitas tenaga kerja, debt service ratio, defisit anggaran terhadap GDP, transportasi dan komunikasi listrik, bunga kredit, real effective exchange rate, dan volatilitas nilai tukar.

2. Kebijakan pemerintah setempat yang diwakili dengan variabel rata-rata impor tarif yang berlaku dan perjanjian bilateral negara tersebut dengan negara lain.

3. Strategi dari perushaan multinasional.

Secara konseptual, pilihan investor asing untuk menanamkan investasinya dalam bentuk FDI, dibanding bentuk modal lainnya di suatu negara, dipengaruhi oleh kondisi dari negara penerima FDI (pull factors) maupun kondisi dan strategi dari penanam modal asing (push factors). Pull factors dari masuknya FDI antara lain terdiri dari kondisi pasar, ketersediaan sumber daya, daya saing, kebijakan yang terkait dengan perdagangan dan industri serta kebijakan liberalisasi FDI ( di dalam bentuk insentif investasi), sedangkan yang termasuk push factors antara lain strategi investasi maupun strategi produksi dari penanam modal, serta persepsi resiko terhadap negara penerima (Kurniati dkk, 2007).

Perusahaan multinasional mempertimbangkan PMA karena diharapkan PMA dapat meningkatkan tingkat keuntungan dan meningkatkan kekayaan pemegang saham. Ketika melakukan PMA, perusahaan harus mempertimbangkan apakah kesempatan yang ada sesuai dengan operasinya. Motif dilakukannya FDI adalah meningkatkan keuntungan, mengurangi biaya dan gabungan keduanya. (Madura, 2010 dalam Sitinjak, 2011).

Menurut Grifin dan Pustay, 2009 (dalam Pambudi dan Hakim, 2013), berdasarkan bentuknya investasi asing langsung (FDI) dapat dibedakan menjadi dua yaitu greenfield dan akuisisi. FDI dengan bentuk greenfield identik dengan pembangunan unit-unit produksi yang baru di negara tujuan investasi (Host Country). Sedangkan FDI dengan bentuk akuisisi dilaksanakan dengan cara 
Fuji A \& Ina Namora P.S. Analisis Produk Domestik Bruto, Infrastruktur, Nilai Tukar Dan Tingkat Suku Bunga Terhadap Investasi Asing Langsung Di Indonesia

membeli sebagian kepemilikan dari perusahaan yang sudah ada sebelumnya di negara tujuan investasi (Host Country).

Menurut Ball dan Mc. Culloh, 1996 (dalam Anastasia, 2010), negara akan menanamkan modal dalam hal ini FDI dipengaruhi faktor ekonomi berupa nilai ekspor, pendapatan riil, inflasi, kurs valuta asing, tingkat bunga, ketersediaan kredit, kebiasaan pembayaran nasabah dan Rate of Return (ROR) investasi yang sama dan faktor non ekonomi yaitu politik dan hukum, sosial budaya dan daya saing.

\section{Menurut Supriana (2008),}

Produk Domestik Bruto dapat diartikan sebagai barang dan jasa yang diproduksi (dengan menggunakan faktor produksi milik warga negara maupun milik warga negara asing yang ada di negara tersebut) dalam satu negara pada tahun tertentu. PDB sering dianggap sebagai ukuran terbaik dari kinerja perekonomian. PDB dapat dilihat sebagai pendapatan total dari setiap orang di dalam perekonomian dan sebagai pengeluaran total atas output barang dan jasa perekonomian. PDB riil yaitu suatu ukuran kemakmuran ekonomi dalam menghitung output barang dan jasa perekonomian dan tidak akan dipengaruhi oleh perubahan harga yang diukur dengan menggunakan harga konstan pada tahun tertentu.

Secara sistematis investasi yang ditentukan oleh PDB (Hasanah dan Sunyoto, 2013) adalah:

$\mathrm{I}=\mathrm{f}(\mathrm{Y})$

$\mathrm{I}=\mathrm{I} 0+\mathrm{cY}$

Di mana :

$\mathrm{I}_{0}=$ Investasi otonomous

$\mathrm{c}=$ MPI $=$ Marginal Propensity to Invest (kecenderungan berinvestasi)

Hubungan investasi asing langsung dengan tingkat PDB dapat diinterpretasikan bahwa kalau PDB suatu negara meningkat maka akan berdampak pada meningkatnya investasi di negara tersebut. Sebaliknya jika suatu negara PDBnya rendah maka akan mempengaruhi tingkat investasi yang rendah juga.

Kegiatan perekonomian tidak terlepas dari dukungan pemerintah, diantaranya adalah dengan menyediakan infrastruktur bagi para investor. Menurut Sari (2015), infrastruktur merupakan sarana dan prasarana yang mendukung kegiatan ekonomi. Infrastruktur meliputi transportasi, komunikasi, utilitas, pembuangan limbah dan lain-lain. Infrastruktur juga merupakan faktor yang 
cukup penting dalam meningkatkan investasi asing langsung. Mengingat infrastruktur yang buruk akan menyulitkan investasi asing untuk menjalankan bidang usahanya. Dengan demikian, apabila pembangunan infrastruktur dilakukan dengan terarah maka peningkatan infrastruktur dapat meningkatkan investasi asing langsung.

Tingkat suku bunga menyatakan tingkat pembayaran terhadap pinjaman atau investasi lain, di atas perjanjian pembayaran kembali, dan dinyatakan dalam persentase tahunan. Suku bunga riil adalah suku bunga yang dikoreksi karena inflasi yang dihitung sebagai suku bunga nominal dikurang tingkat inflasi. Stabilitas suku bunga sangat diharapkan, karena stabilitas suku bunga mendorong pula terjadinya stabilitas pasar keuangan sehingga kemampuan pasar keuangan untuk menyalurkan dana dari orang yang memiliki peluang investasi produktif dapat berjalan lancar dan kegiatan perekonomian juga tetap stabil (Mishkin, 2008).

Kaum klasik berpandangan bahwa besar kecilnya investasi adalah tergantung dari besar kecilnya tingkat bunga. Jadi bila tingkat bunga tinggi maka investasi akan semakin kecil, sebaliknya bila tingkat bunga rendah maka tingkatinvestasi akan semakin tinggi. Berdasarkan pandangan ini, maka investasi adalah fungsi dari tingkat bunga :

$$
\mathrm{I}=\mathrm{f}(\mathrm{r})=\frac{\Delta I}{\Delta r}=\mathrm{e}
$$

Dalam jangka pendek, maka fungsi dari investasi adalah sebagai berikut :

$\mathrm{I}=\mathrm{I}_{0}-\mathrm{er}$, di mana (e) berlambang negatif, karena hubungan terbaliknya antara investasi dan suku bunga. (Putong dan Andjaswati (2008).

Investasi bergantung pada tingkat bunga riil karena tingkat bunga adalah biaya pinjaman. Dengan demikian suku bunga riil juga merupakan salah satu variabel utama yang digunakan perusahaan untuk mempertimbangkan apakah rencana suatu proyek baru akan menguntungkan secara keuangan atau tidak. (Sitinjak, 2011).

Kurs riil (Real Exchange Rate) adalah harga relatif dari barang-barang di antara dua negara. Kurs riil menyatakan tingkat di mana kita bisa memperdagangkan barang-barang dari suatu negara untuk barang-barang dari negara lain.

Kebutuhan terhadap nilai tukar/ kurs timbul dari hubungan perdagangan internasional melalui adanya permintaan 
Fuji A \& Ina Namora P.S. Analisis Produk Domestik Bruto, Infrastruktur, Nilai Tukar Dan Tingkat Suku Bunga Terhadap Investasi Asing Langsung Di Indonesia

dan penawaran terhadap beberapa mata uang sebagai media atau alat tukar di negara lain. Menurut Tambunan (2015), kurs (exchange rate) adalah nilai tukar suatu mata uang sebuah negara. Kurs riil (Real Exchange Rate) adalah suatu harga relatif dari barang-barang di antara dua negara. Ketika kurs riil tinggi, maka barang-barang luar negeri relatif murah dan barang-barang domestik relatif mahal. Sebaliknya, jika kurs riil rendah, maka barang-barang luar negeri relatif mahal dan barang-barang domestik relatif murah. Dalam jangka pendek, penurunan kurs akan mengurangi investasi melalui pengaruh negatifnya pada absorbs domestic atau yang dikenal dengan expenditure reducing effect. Karena penurunan tingkat kurs ini akan menyebabkan nilai riil asset masyarakat yang disebabkan kenaikan tingkat hargaharga secara umum dan selanjutnya akan menurunkan permintaan domestik masyarakat. Gejala di atas pada tingkat perusahaan akan direspon dengan penurunan pada pengeluaran / alokasi modal pada investasi. (Letarisky dkk, 2014).

\section{METODE PENELITIAN}

Metode penelitian yang digunakan dalam penelitian ini adalah kuantitatif. Menurut Noor (2011), penelitian kuantitatif merupakan metode untuk menguji teoriteori tertentu dengan cara meneliti hubungan antarvariabel. Pendekatan ini berangkat dari data. Jenis penelitian ini merupakan penelitian deskriptif kuantitatif. Menurut Sujarweni (2015), penelitian deskriptif adalah penelitian yang dilakukan untuk mengetahui nilai masing-masing variabel, baik satu variabel atau lebih sifatnya independen tanpa membuat hubungan maupun perbandingan dengan variabel lain. Metode pengumpulan data yang dilakukan dalam penelitian ini adalah metode tidak langsung (indirect method) yaitu dokumentasi melalui pencatatan atau mendownload data. Jenis data yang digunakan dalam penelitian ini adalah data sekunder dalam bentuk data runtun waktu (time series), dengan periode penelitian dari tahun 1998 hingga tahun 2015. Data diambil dari berbagai sumber resmi dari Bank Indonesia (BI), Badan Pusat Statistik (BPS), Federal Reserve Bank of St. Louis dan United Nations Economic Social Pacific (UNESCAP). Teknik analisis yang 
digunakan untuk menganalisis model dalam penelitian ini adalah Ordinary Least Square (OLS) dan Error Correction Model (ECM).

Adapun model penelitian menggunakan persamaan regresi linier berganda. Model dasar dalam penelitian ini dapat disusun sebagai berikut :

$$
\begin{aligned}
\text { FDI }= & f(P D B, I N F R A, I R, E) \ldots \ldots . . .(3.1) \\
\text { FDI }= & \beta 0+\beta 1 P D B+\beta 2 I N F R A+\beta 3 I R \\
& +\beta 4 E+\varepsilon i
\end{aligned}
$$

Fungsi persamaan (3.2) diubah ke dalam bentuk persamaan logaritma natural sebagai berikut :

$$
\begin{aligned}
\operatorname{LnFDI}= & \beta_{0}+\beta_{1} \operatorname{Ln} P D B+\beta_{2} \operatorname{LnINFRA}+ \\
& \beta_{3} I R+\beta_{4} E+\varepsilon i \ldots \ldots \ldots . .
\end{aligned}
$$

Di mana :

FDI = Foreign Direct Investment

(Investasi Asing Langsung).

PDB = Produk Domestik Bruto

INFRA = Infrastruktur

IR = Tingkat suku bunga riil

$\mathrm{E}=$ Nilai tukar Rupiah

Ln = Logaritma natural

$\beta 0=$ Konstanta

$\beta 1: \beta 2: \beta 3: \beta 4=$ Koefisien regresi

gi = variabel gangguan (disturbance

error)

Model logaritma natural merupakan model log-log atau model double-log atau log linier yang dapat mengukur elastisitas suatu variabel. Salah satu ciri menarik dari model log-log yang menjadikan model ini sangat populer untuk digunakan adalah koefisien kemiringan $\beta 1: \beta 2: \beta 3$ : $\beta 4$ yang mengukur elastisitas $\mathrm{Y}$ terhadap $X$, yaitu persentase perubahan Y jika terjadi persentase perubahan (kecil) dari X. Jika Y menunjukkan kuantitas permintaan barang dan $\mathrm{X}$ adalah unit harga, maka $\beta 1: \beta 2: \beta 3: \beta 4$ mengukur elastisitas harga dari permintaan, parameter yang sangat penting dalam ekonomi. (Gujarati : 2010).

\section{Persamaan Model Koreksi} Kesalahan (ECM) - Engle Granger dari persamaan (3.3) yang akan diestimasi, sehingga dapat ditulis sebagai berikut :

$$
\begin{array}{r}
\Delta L n F D I=\alpha_{0+} \quad \alpha_{1} \Delta L n P D B+ \\
\alpha_{2} \Delta L n I N F R A+\quad \alpha_{3} \Delta I R+ \\
\alpha_{4} \Delta E+\alpha_{5}\left(\operatorname{Ln} F D I_{t-1}-\beta_{0}-\right. \\
\beta_{1} L n P D B_{t-1}-\beta_{2} \operatorname{LnINFRA} \\
\left.t_{-1}-\beta_{3} I_{t-1}-\beta_{4} E_{t-1}\right)+v i
\end{array}
$$

atau dapat ditulis menjadi : 
Fuji A \& Ina Namora P.S. Analisis Produk Domestik Bruto, Infrastruktur, Nilai Tukar Dan Tingkat Suku Bunga Terhadap Investasi Asing Langsung Di Indonesia

$$
\begin{gathered}
d L n F D I=\quad \alpha_{0+} \quad \alpha_{1} d L n P D B+ \\
\alpha_{2} d L n I N F R A+\alpha_{3} d I R+\alpha_{4} d E \\
\left.+\alpha_{5} E C T \ldots \ldots \ldots . .3 .5\right)
\end{gathered}
$$

Di mana :

Ln = Logaritma Natural

$\mathrm{D} \quad=$ First Difference

$\mathrm{ECT}=$ Error Correction Term

Koefisien $\alpha_{1}, \alpha_{2}, \alpha_{3}, \alpha_{4}, \alpha_{5}=$

koefisien regresi jangka pendek

Koefisien $\alpha_{6}=$ koefisien koreksi

ketidakseimbangan (speed of

adjustment)

\section{HASIL DAN PEMBAHASAN}

\section{Hasil Pengecekan Pengujian}

\section{Stasioneritas Data}

Tabel 4.1 Hasil Uji Akar Unit (Unit Root Test)

Pada Tingkat Level

\begin{tabular}{|l|l|l|l|l|}
\hline No & Variabel & Level & Prob. PP & Kesimpulan \\
\hline 1 & LnFDI & Level & 0.5048 & $\begin{array}{l}\text { Tidak } \\
\text { Stasioner }\end{array}$ \\
\hline 2 & LnPDB & Level & 0.9807 & $\begin{array}{l}\text { Tidak } \\
\text { Stasioner }\end{array}$ \\
\hline 3 & LnInfra & Level & 0.9964 & $\begin{array}{l}\text { Tidak } \\
\text { Stasioner }\end{array}$ \\
\hline 4 & E & Level & 0.9142 & $\begin{array}{l}\text { Tidak } \\
\text { Stasioner }\end{array}$ \\
\hline 5 & IR & Level & 0.1104 & $\begin{array}{l}\text { Tidak } \\
\text { Stasioner }\end{array}$ \\
\hline
\end{tabular}

Sumber : Data diolah dengan Eviews.

Dari hasil empiris pada tabel 4.1 di atas, dapat dilihat bahwa seluruh variabel tidak ada yang stasioner pada tingkat level. Hal ini dapat dilihat dari probabilty PP yang diperoleh lebih besar dari $\alpha=0.05$.

Tabel 4.2 Hasil Uji Akar Unit (Unit Root Test) Pada First Difference

\begin{tabular}{|l|l|l|l|l|}
\hline No & Variabel & Level & $\begin{array}{l}\text { Prob. } \\
\text { PP }\end{array}$ & $\begin{array}{l}\text { Kesimpu } \\
\text { lan }\end{array}$ \\
\hline 1 & D(LnFDI) & $\begin{array}{l}\text { First } \\
\text { difference }\end{array}$ & 0.0000 & Stasioner \\
\hline 2 & $\begin{array}{l}\text { D(LnPDB } \\
\text { j }\end{array}$ & $\begin{array}{l}\text { First } \\
\text { difference }\end{array}$ & 0.0015 & Stasioner \\
\hline 3 & $\begin{array}{l}\text { D(LnInfr } \\
\text { a) }\end{array}$ & $\begin{array}{l}\text { First } \\
\text { difference }\end{array}$ & 0.0216 & Stasioner \\
\hline 4 & D(E) & $\begin{array}{l}\text { First } \\
\text { difference }\end{array}$ & 0.0001 & Stasioner \\
\hline 5 & D(IR) & $\begin{array}{l}\text { First } \\
\text { difference }\end{array}$ & 0.0001 & Stasioner \\
\hline \multicolumn{3}{|l|}{ Sumber : Data diolah dengan Eviews }
\end{tabular}

Dari tabel (4.2) dapat dilihat bahwa semua variabel stasioner pada first difference. Hal ini dapat dilihat dari probabilty PP yang diperoleh lebih kecil dari $\alpha=0.05$

\section{Hasil Estimasi Persamaan Regresi Linier Berganda (Jangka Panjang)}

Setelah dilakukan uji akar unit, maka dilakukan estimasi persamaan regresi linier berganda (persamaan jangka panjang) dengan teknik Ordinary Least Square (OLS). Adapun hasil empiris yang didapat sbb :

$$
\begin{array}{r}
\text { LNFDI }=183.6154+6.262174 * \\
\text { LNPDB }-22.54252 * \text { LNInfra }+ \\
\text { 0.264626E }-0.017464 * \text { IR .. (5.1) }
\end{array}
$$

Dari hasil empiris ini menunjukkan bahwa dalam jangka panjang variabel infrastruktur (Infra), Pendapatan 
Domestik Bruto riil (PDB), tingkat suku bunga (IR) dan nilai tukar (E) berpengaruh terhadap investasi asing langsung di Indonesia dalam perkembangan ekonomi global.

\section{Hasil Pengecekan Pengujian Kointegrasi}

Dari hasil estimasi pada tabel 4.3 diperoleh bahwa nilai ADF statistik $3.876946>$ nilai kritis $\alpha=5 \%(-3.052169)$ dengan nilai probability $0.0102<\alpha=0.05$. Sehingga menunjukkan bahwa variabel saling berkointegrasi atau mempunyai hubungan jangka panjang.

\section{Hasil Estimasi Persamaan Jangka Pendek (Error Correction Mechanism)}

Untuk melakukan koreksi dari ketidakseimbangan yang terjadi dalam jangka pendek dengan memasukkan nilai penyesuaian (adjustment) menuju pada keseimbangan jangka panjang, untuk itu dilakukan estimasi model ECM dari persamaan (4.2) dan diperoleh hasil empiris berikut :

$$
\mathrm{D}(\text { LNFDI })=-2.596686+4.998224 * \mathrm{D}
$$$$
\begin{aligned}
& (\text { LNPDB })+94.14938 * \\
& \mathrm{D}(\text { LNInfra })+0.274132 * \mathrm{D}(\mathrm{E})+ \\
& 0.095576 * \mathrm{D}(\mathrm{IR})-1.300389 * \\
& \text { ECT }(-1)
\end{aligned}
$$

Berdasarkan hasil empiris dari persamaan (5.2) di atas dapat diinterpretasikan bahwa nilai koefisien koreksi ketidakseimbangan atau speed of adjustment memiliki tanda nilai negatif dan signifikan secara statistik dengan probabilitas ECT $0.0004<0.05$. Maka model ECM yang digunakan telah valid (tepat) untuk dipilih menjadi model empirik.

Nilai koefisien dari ECT (speed of adjustment) $\quad$ sebesar $\quad 1.300389$ menunjukkan bahwa ada sebesar $30.03 \%$ ketidakseimbangan pada pengaruh jangka pendek perubahan variabel infrastruktur, produk domestik bruto, tingkat suku bunga dan nilai tukar terhadap investasi asing langsung di Indonesia dalam perkembangan ekonomi global.

Kenaikan infrastruktur (Infra) sebesar 1 satuan akan menyebabkan kenaikan investasi asing langsung di Indonesia dalam perkembangan ekonomi global sebesar 94.14938 satuan.

Kenaikan produk domestik bruto (PDB) sebesar 1 satuan akan menyebabkan kenaikan investasi asing langsung di Indonesia dalam perkembangan ekonomi global sebesar 4.998224 satuan. 
Kenaikan tingkat suku bunga (IR) sebesar 1 satuan akan menyebabkan kenaikan investasi asing langsung di Indonesia dalam perkembangan ekonomi global sebesar 0.095576 satuan.

Kenaikan nilai tukar rupiah (E) sebesar 1 satuan akan menyebabkan kenaikan investasi asing langsung di Indonesia dalam perkembangan ekonomi global sebesar 0.274132 satuan.

\section{Koefisien Determinasi $\left(\mathbf{R}^{\mathbf{2}}\right)$}

Dari hasil empiris menunjukkan estimasi output persamaan regresi dengan metode ECM, memiliki nilai R-squared sebesar 0,781703 dan nilai Adjusted Rsquared sebesar 0.682477 . Nilai koefisien determinasi $\left(\mathrm{R}^{2}\right)$ yang digunakan dalam penelitian ini adalah nilai R-squared sebesar 0.781703. Hal ini menunjukkan bahwa variasi dari variabel infrastruktur, produk domestic bruto, tingkat suku bunga dan nilai tukar rupiah mampu menjelaskan sebesar $78,17 \%$ variasi variabel investasi asing langsung di Indonesia dalam perkembangan ekonomi global sedangkan sisanya $21,83 \%$ dijelaskan oleh variabelvariabel di luar dari penelitian ini.

Hasil Pengecekan Pengujian Asumsi Klasik Hasil Uji Normalitas

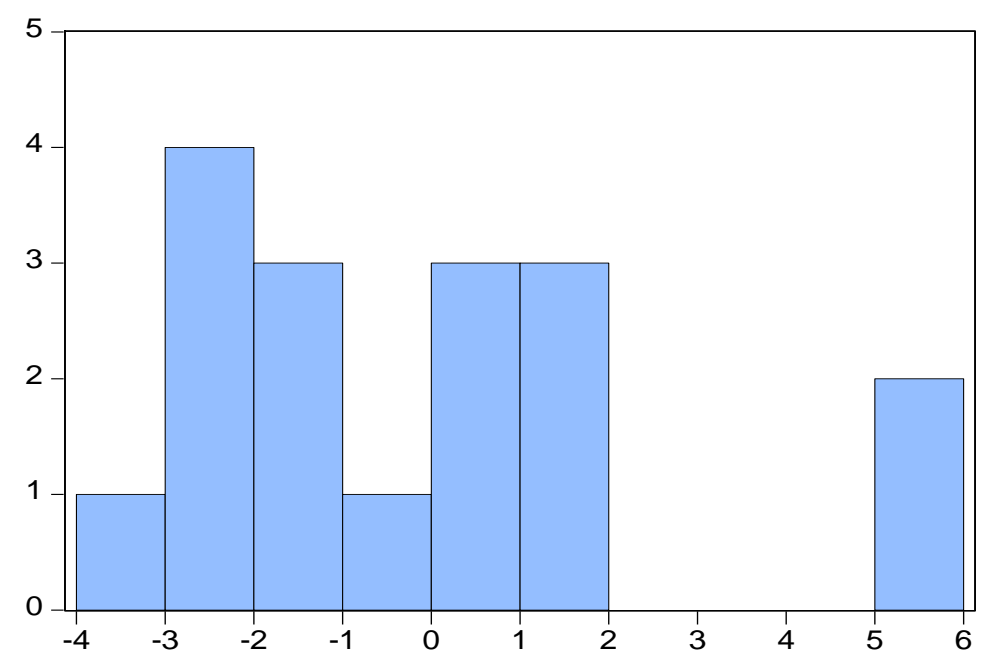

\begin{tabular}{ll}
\hline \multicolumn{2}{l|}{ Series: Residuals } \\
Sample 1999 2015 \\
Observations & 17 \\
Mean & $-1.18 \mathrm{e}-16$ \\
Median & -0.685876 \\
Maximum & 5.852064 \\
Minimum & -3.133335 \\
Std. Dev. & 2.584225 \\
Skewness & 1.019550 \\
Kurtosis & 3.305819 \\
& \\
Jarque-Bera & 3.011444 \\
Probability & 0.221857 \\
\hline
\end{tabular}

Sumber : Data diolah (Eviews)

Gambar 4.1 Histogram dan Statistik Jarque Bera

Berdasarkan hasil uji normalitas pada gambar 4.1 bahwa nilai statistik JB- test dengan angka probability $0.221857>\alpha$ $=0.05$ dapat disimpulkan tidak signifikan, 
hal ini berarti menerima hipotesis dan telah berdistribusi normal. bahwa residual atau faktor penggangu

Tabel 4.3 Hasil Uji Korelasi Variabel-Variabel Independen

\begin{tabular}{|l|c|c|c|c|}
\hline Variabel & $\mathrm{D}(\mathrm{LNPDB})$ & $\mathrm{D}($ LNINFRA $)$ & $\mathrm{D}(\mathrm{E})$ & $\mathrm{D}(\mathrm{IR})$ \\
\hline $\mathrm{D}(\mathrm{LNPDB})$ & 1.000000 & 0.167650 & -0.123508 & -0.178342 \\
\hline $\mathrm{D}($ LNINFRA $)$ & 0.167650 & 1.000000 & 0.124647 & -0.731930 \\
\hline $\mathrm{D}(\mathrm{E})$ & -0.123508 & 0.124647 & 1.000000 & 0.109954 \\
\hline $\mathrm{D}(\mathrm{IR})$ & -0.178342 & -0.731930 & 0.109954 & 1.000000 \\
\hline
\end{tabular}

\section{Hasil Uji Multikolinieritas}

Tabel 4.4 Hasil Uji Multikolinieritas Dengan Metode VIF

\begin{tabular}{|l|l|l|l|l|}
\hline Variabel & $\mathrm{D}($ LNPDB $)$ & $\mathrm{D}($ LNINFRA $)$ & $\mathrm{D}(\mathrm{E})$ & $\mathrm{D}(\mathrm{IR})$ \\
\hline $\mathrm{D}(\mathrm{LNPDB})$ & 1.000000 & 1.028919345 & 1.015490522 & 1.032850714 \\
\hline $\mathrm{D}($ LNINFRA $)$ & 1.028919345 & 1.000000 & 1.015782079 & 2.153879737 \\
\hline $\mathrm{D}(\mathrm{E})$ & 1.015490522 & 1.015782079 & 1.000000 & 1.012237836 \\
\hline $\mathrm{D}(\mathrm{IR})$ & 1.032850714 & 2.153879737 & 1.012237836 & 1.000000 \\
\hline
\end{tabular}

Berdasarkan tabel 4.4 bahwa nilai koefisien korelasi $\left(\mathrm{r}^{2}\right)$ antar variabel bebas tidak ada yang memiliki nilai melebihi 0.9. Namun, untuk lebih memastikan dapat dilakukan uji berikutnya dengan menggunakan metode Variance Inflation Factor (VIF) dari nilai korelasi pada tabel 4.4 di atas. Rumus untuk mencari nilai VIF $=1 /\left(1-\mathrm{r}^{2}\right)$.
Adapun hasil empiris untuk pengecekan uji VIF dapat dilihat pada tabel 4.5 berikut :

Dilihat dari hasil empiris tabel 4.4 bahwa nilai VIF dari korelasi variabelvariabel bebas tidak ada yang melebihi angka 10. Maka dapat disimpulkan bahwa antar variabel bebas tidak terjadi multikolinieritas. 
Fuji A \& Ina Namora P.S. Analisis Produk Domestik Bruto, Infrastruktur, Nilai Tukar Dan Tingkat Suku Bunga Terhadap Investasi Asing Langsung Di Indonesia

Hasil Uji Autokorelasi

Tabel 4.6 Hasil Uji Autokorelasi Metode BG

Breusch-Godfrey Serial Correlation LM Test:

\begin{tabular}{cccc}
\hline \hline F-statistic & 0.524246 & Prob. F(1,15) & 0.6090 \\
Obs*R-squared & 1.773834 & Prob. Chi-Square(1) & 0.4119 \\
\hline \hline
\end{tabular}

Dari hasil empiris yang ada pada tabel 4.7 nol (Ho) tidak dapat ditolak. Dapat diatas dapat dilihat bahwa nilai dikatakan bahwa model tidak mengandung probabilitas chi-squares lebih besar dari autokorelasi.

nilai $\alpha=0,05$. Dengan demikian hipotesis

Hasil Pengecekan Uji Statistik

Hasil Uji Simultan (Uji F)

\begin{tabular}{crccc}
\multicolumn{5}{c}{ Tabel 4.7 Hasil Uji Statistik } \\
Variable & Coefficient & Std. Error & t-Statistic & Prob. \\
C & -0.006744 & 0.009399 & -0.717487 & 0.4834 \\
D(LnPDB) & 4.998224 & 2.054387 & 2.432952 & 0.0332 \\
D(LnInfra) & 94.14938 & 40.22822 & 2.340382 & 0.0391 \\
D(IR) & 0.274132 & 0.111989 & 2.447841 & 0.0324 \\
D(IR) & 0.095576 & 0.081619 & 1.171010 & 0.2663 \\
ECT(-1) & -0.445808 & 0.175763 & -2.536421 & 0.0220 \\
F-statistic & 7.878023 & Prob(F-statistic) & 0.002246
\end{tabular}

Dari tabel 4.8 dapat dilihat nilai F Hasil Uji Parsial (Uji t)

statistik sebesar 7.878023 dengan Berdasarkan hasil pengujian secara parsial probabilitas statistik sebesar 0.002246 (uji t) yang dapat dilihat pada tabel $4.8 \mathrm{di}$ lebih kecil dari $\alpha=0,05$ yang atas, hasil empiris memperlihatkan dari 4 menunjukkan bahwa secara simultan (empat) variabel independen yang diteliti (serempak) semua variabel hanya 3 (tiga) variabel yang berpengaruh independen yaitu infrastruktur, produk signifikan terhadap investasi asing domestik bruto, dan nilai tukar, serta langsung di Indonesia dalam Error Correction Term (ECT) memiliki perkembangan ekonomi global yaitu pengaruh yang signifikan terhadap variabel infrastruktur, produk domestik investasi asing langsung di Indonesia bruto, dan nilai tukar. Hal ini dapat dilihat dalam perkembangan ekonomi global. dari nilai probabilitas statistik lebih kecil dari $\alpha=0,05$. Sedangkan variabel tingkat suku bunga tidak mempengaruhi investasi asing langsung di Indonesia dalam 
perkembangan ekonomi global.

\section{SIMPULAN}

1. Dari hasil estimasi yang diperoleh, secara parsial variabel produk domestik bruto, infrastruktur dan nilai tukar rupiah berpengaruh positif dan signifikan terhadap investasi asing langsung di Indonesia dalam perkembangan ekonomi global. Sedangkan variabel tingkat suku bunga berpengaruh positif dan tidak signifikan terhadap investasi asing langsung di Indonesia dalam perkembangan ekonomi global.

2. Dari hasil estimasi yang diperoleh bahwa secara simultan variabel produk domestik bruto, infrastruktur, nilai tukar rupiah dan tingkat suku bunga terhadap investasi asing langsung di Indonesia dalam perkembangan ekonomi global.

3. Besarnya nilai koefisien variabelvariabel yang menjelaskan variabel investasi asing langsung dalam perkembangan ekonomi global, yang terbesar adalah infrastruktur, kemudian diikuti oleh produk domestik bruto, nilai tukar rupiah.

\section{DAFTAR PUSTAKA}

Anastasia, Henny Maria. (2010). Faktor-Faktor Ekonomi Makro yang Mempengaruhi Investasi Asing Langsung (FDI) pada Sektor Perkebunan di Indonesia Periode (Tahun
1980 - 2007). Tesis. Magister dan Perencanaan Kebijakan Publik Kekhususan Infrastruktur. Universitas Indonesia.

Hasanah, Erni Umi dan Sunyoto, Danang. (2013). Pengantar Ilmu Ekonomi Makro (Teori dan Soal). Penerbit Buku Seru : Jakarta.

Kurniati, dkk. (2007). Determinan FDI (FaktorFaktor yang Menentukan Investasi Asing Langsung). Working Paper Bank Indonesia WP/06/2007.

Letarisky, Monica., Darminto dan Hidayat, Rustam R. (2014). Pengaruh Indiktor Fundamental Makroekonomi terhadap Foreign Direct Investment di Indonesia (Periode Tahun 2004-2013). Jurnal Administrasi Bisnis (JAB)15(2).

Mishkin, Frederic S. (2008). The Economics of Money, Banking and Financial Markets : Ekonomi Uang, Perbankan dan Pasar Keuangan. Edisi Kedelapan (terjemahan), Penerbit Salemba Empat : Jakarta

Mudrajad, Kuncoro. (2009). Ekonomi Pembangunan Teori, Masalah dan Kebijakan. (UPP) AMP YKPN : Yogyakarta.

Noor, Juliansyah. (2011). Metodologi Penelitian Skripsi, Tesis, Disertasi, dan Karya Ilmiah. Penerbit Kencana Prenada Media Group : Jakarta.

Pambudi, Adhib Eka dan Hakim, Lukman. (2013). Perbandingan Faktor Ekonomi Makro dan Karakteristik Negara Sebagai Determinan FDI di ASEAN 5 dan China periode 19882009. Dinamika Jurnal Ekonomi Pembangunan. 5(1), Februari 2013.

Purba, dkk. (2015). Pengaruh Impor dan Nilai Tukar terhadap Investasi Asing Langsung di Indonesia (Studi pada Bank Indonesia Periode Kuartal I 2006 - Kuartal IV 2013). Jurnal Administrasi Bisnis (JAB), 28(1).

Putong, Iskandar dan Andjaswati, N.D. (2008). Pengantar Ekonomi Makro. Edisi Ke Satu. Jakarta. Penerbit Mitra Wacana Media

Sitinjak, Robudi Musa. (2011). Analisis Faktorfaktor yang Mempengaruhi Penanaman Modal Asing Langsung di Indonesia. Tesis. MPKP FE UI, Universitas Indonesia

Sari, Rini Kurnia. (2015). Analysis of Factors that

Effects the Investors in Conducting Business in Indonesia. Binus Business Review, 6(3)

Supriana, Tavi. (2008). Ekonomi Makro. Medan. USU PRESS

Tambunan, Rexsy S. (2015). Pengaruh Kurs, Inflasi, Libor dan PDB terhadap Foreign Direct Investment (FDI) di Indonesia. JOM FEKON,2(1). 
Fuji A \& Ina Namora P.S. Analisis Produk Domestik Bruto, Infrastruktur, Nilai Tukar Dan Tingkat Suku Bunga Terhadap Investasi Asing Langsung Di Indonesia

Undang-Undang Republik Indonesia No 25 Tahun

2007 : Penanaman Modal Asing. 